Ilaria L. E. Ramelli

\title{
Institutionalisation of religious individualisation: asceticism in antiquity and late antiquity and the rejection of slavery and social injustice
}

\section{Methodological Introduction: Religious individualisation, asceticism, and justice in imperial and late antiquity}

Phenomena related to religious individualisation existed, and were important, already in classical antiquity and late antiquity. ${ }^{1}$ A major issue that is closely related to religious individualisation in historical perspective ${ }^{2}$ is the practice of personal piety, and specifically of asceticism, in antiquity and late antiquity with a focus on one's own body, soul, passions, and intellect/nous, with a view to a 'unified nous' (Evagrius). My focus in this paper will be on imperial and late antiquity, the long period over which Jörg Rüpke has identified a change in practices and assumptions, which he calls 'individualisation'. ${ }^{3}$

The definition of asceticism is complex. What emerges from an accurate analysis is that ancient and late antique philosophical asceticism involved not only dietary and sexual restrictions, and not simply a mortification of the body, as a kind of new martyrdom or even new sacrifice (on whose varieties in Roman times see Schultz 2016), but also voluntary poverty, voluntary service to others, refraining from oppressing other people, and the like, all as part and parcel of piety towards the divine. This emphasis on poverty, voluntary service to others, refraining from oppression, and the like is not common to all strands of asceticism (neither in antiquity, nor today: see Logan 2017), but is stressed both in

1 See Fuchs, Mulsow, Rüpke 2016, 5. This is an etic category; I refer to its discussion as a semantic matrix in Otto 2017. See also Rüpke 2013, which analyses both the individual and its socialisation - its integration into ever larger social contexts - in ancient Mediterranean religions from Hellenism to late antiquity, including Seneca's philosophical reflections (Aldo Setaioli, 'Cicero and Seneca on the Fate of the Soul: Private Feelings and Philosophical Doctrines', Chap. 17). Concrete examples of individualisation in Roman religion are in Rüpke 2016. On religious individuality in gnosticism see Markschies 2014.

2 See Fuchs, Rüpke 2015; Fuchs 2015; Rüpke 2015.

3 Rüpke 2011/2017; 2014. See also Rüpke 2013a; Spickermann, Rüpke 2012.

2 Open Access. (C) 2019 Ilaria L. E. Ramelli, published by De Gruyter. (c) BY-NC-ND This work is licensed under a Creative Commons Attribution-NonCommercial-NoDerivatives 4.0 International License. https://doi.org/10.1515/9783110580853-035 
the Pythagorean tradition that was Christianised through the Sentences of Sextus and in patristic philosophy, especially the 'Origenian' line, which represents the quintessential philosophical asceticism of the ancient Christian tradition. ${ }^{4}$ As Anna Williams $(2007,7)$ has remarked, ascetic texts 'do not display their authors' interest in ascesis because ascesis is a worthy or superior substitute for intellectual activity, but because the latter is infeasible without control of the emotions and bodily desires'. The concern for justice is paramount both in the harmony of the single person's faculties, including the control of passions (i.e. negative emotions) and desires that are so central in, for instance, Evagrius, and in the harmony within humanity as a whole, with an equal distribution of goods and without the oppression of some by others.

Elements of ascetic practice which were present all together or selectively in given groups of ascetics, included sleep and food deprivation, chastity, poverty, renunciation of honours and of any form of violence and oppression of other people, along with much else. In the various forms that ancient asceticism assumed, some aspects were more emphasised than others. Some, for instance, placed greater stress on sexual and nutritional control and less on poverty and the renunciation of oppression; others, on the contrary, attached more importance to the latter than to the former aspects. The ascetics who made the most of the renunciation of oppression and injustice were also more likely to renounce both slave ownership and wealth, which was perceived as the cause of the poverty of other people and, thereby, of social injustice. ${ }^{5}$

Peter Brown's highly influential analysis (1988/2008) concentrates on only one facet of asceticism, sexual restraint in the first five centuries of Christianity, but there were many other kinds of self-control. Even virginity itself was conceived of very broadly by ascetics such as Origen, Methodius, and Gregory Nyssen, to the point of embracing the whole of the self-discipline that aimed at apatheia, the eradication of passions from one's soul with a view to purification, as the first stage in the ascent to contemplation. In late-antique Christianity, monasticism, both anchoritic and cenobitic, was the privileged environment for the application of asceticism. William Harmless (2009) rightly insists not only on the renunciation of marriage, family, and any sexual activity as marks of asceticism, but also on the renunciation of wealth, property, and career, the taking up of manual labour, and the deprivation of food and sleep. Cenobitic asceticism was already practiced by Essenes and Therapeutae in the Jewish world, and it is precisely such ascetic circles, both Jewish and Christian, that provide the most

4 See Ramelli 2016. On theological perspectives on slavery see also Priesching, Grieser 2016.

5 On the notion of social justice see Ramelli 2016, introduction and conclusion, and Feldman 2016. 
remarkable instances of the rejection of slavery as an institution, as well as a broader rejection of both social injustice and oppression.

As recent scholarship has emphasised (Griffin-Ramelli 2019), asceticism 'pagan' philosophical, Jewish, and Christian - in antiquity and late antiquity is not hatred of the body, not even in the Platonic tradition. Asceticism was not simply about the refinement of the body: in both 'pagan' and Christian Platonism, the ascent through the hierarchy of bodies reflects a purification and progress of the soul. Origen spelt out this soul-body correlation in the best way: each soul must be in a corporeal state that is appropriate to its rank or order, by which he means its level of moral development (Ramelli 2018). For several ascetics, in particular the philosophical ascetics of Hellenistic Judaism and especially late antique Christianity, the progress of the soul involved justice, solidarity with other people, and renouncing the oppression of fellow humans that came through the ownership of slaves and the impoverishment of others that was a result of possessing excessive wealth.

\section{Asceticism and the rejection of oppression: human dignity and Gregory of Nyssa's arguments against slavery and socio-economic injustice}

I shall outline the main strands of the research I have conducted into the role of philosophical asceticism as a personal and group religious practice (2016) and its echoes in the opposition to social injustice and slavery found across religious traditions ('pagan', Hellenistic Jewish, and Christian) throughout the Mediterranean world in imperial and late antiquity. My study points out how private and group ascetic practice played a substantial role in the rejection of slavery, oppression, and social injustice in this period and seeks to connect asceticism, the rejection of the institution of slavery, and the embrace of social justice as they are found in ancient philosophy, Jewish Hellenism, and especially Christian antiquity and late antiquity. When Christian ascetics chose poverty and low status in service to Christ, were they simply withdrawing from social duties, or were they also concerned for those who were socially enslaved or dispossessed? Since at least some Christian (and Jewish, and 'pagan', as we shall see) philosophical ascetics spoke explicitly of justice in this connection, we can surmise that at least some of them embraced asceticism also for the sake of justice.

In voluntary poverty and the giving up of slavery, a deeper level of asceticism was often at work: the principle of renouncing the oppression of fellow humans 
and thereby the commission of injustice against them, either by claiming to own other people or by accumulating wealth, which latter automatically meant, in the judgement of these ascetics, stealing the necessary from the poor. This is the patristic tenet that wealth is tantamount to theft (Ramelli 2016, Chap. 6). Renunciation of oppression and injustice was, at least in the case of the best ascetics, the common root of both the rejection of slavery and the rejection of social injustice through the embrace of voluntary poverty. The necessary and deep interrelation between the two thus turns out to derive from a common origin rather than being a mere juxtaposition. Other options were also available for the second point, social injustice, such as - instead of voluntary poverty - almsgiving in a variety of degrees. This represented a milder form of the reduction of social injustice and oppression.

In some cases, we can even see the development of a notion of 'human dignity' and, as we would call them, individual human rights. This is especially clear in Gregory of Nyssa's strong theological arguments for the rejection of slavery and social injustice on the grounds that they lead to the dire poverty of some people, especially his 'theology of the image', which bestows a unique dignity on every human being qua image of God. Gregory rejected the legitimacy of the institution of slavery and his theological arguments against this institution parallel his theological arguments against the social injustice which resulted in great poverty for many.

Gregory's main argument against slavery is found in a Homily for the Holy Easter (In S. Pascha, 379) and especially in his fourth Homily on Ecclesiastes (GNO 5.334-52). Gregory begins by presenting Easter as the feast of liberation. He describes the manumissio in ecclesia as 'good and humane' because it sets slaves free and does so in a dignified way (GNO 9.1.250.15-20). Gregory here assimilates slave owners to Pharaoh (GNO 9.1.250.24), who elsewhere in his works symbolises evil and the devil. Gregory, unlike many other early Christian thinkers, used arguments concerning spiritual slavery to conclude that legal slavery was illegitimate and against God, and therefore had to be abolished.

Gregory urges masters to release their slaves immediately, on that very day. He qualifies manumission as 'good' (áya日óv, 251.2), as opposed to slavery, which is evil. Note that Gregory urges not only ascetics, but all the heads of households in his audience to manumit all slaves. He argues that, if prisoners are freed when a new member of the royal family is born, or on a military victory, all the more must slaves be freed on the day of Christ's victory over death and his resurrection. Gregory's plea extends to all those afflicted, such as the indigent/beggars ( $\pi \tau \omega \chi 0 i)$ and the sick. The association of slaves with the poor is no accident in Gregory, who used the same theological arguments to denounce as illegitimate both the institution of slavery and the social injustice that led to poverty. Gregory 
regarded the misfortunes of the poor and the sick as a totally undeserved product of the greed of others. Gregory's appeal to choose 'virtue' and reject 'evil' in the peroration of his Paschal homily implies that he regards owning slaves as evil and manumitting them as virtuous. He admits of no exception: all masters should free their slaves. These are humans and, thanks to Christ's Paschal work, all humans 'inherit God', the supreme Good (GNO 9.1.251.21). Humans inherit God fully in the end, at the perfection of all, but already here and now they are heirs of God, because Christ's resurrection contains in nuce, and prefigures, the final resurrection-restoration of all humanity (Ramelli 2013, 372-440).

Slavery is illegitimate and against God because every human is free, in that she or he is God's image. This argument is brought forth especially in Gregory's fourth homily on Ecclesiastes. From the beginning (334), Gregory criticises a human who presumes to be the 'master of fellow humans'. This is an 'outlandish presumption'. No one can claim to possess another human being, which would be 'against God', since all humans belong only to God. Those who claim to own other persons are stealing God's possession (335) and go against God and God's decree, which made all humans free and endowed them with freewill: 'You condemn to slavery the human being, whose nature is free and self-determining, and so you make laws that are contrary to that of God'. God made each person the master of all creation, and anyone who dares enslave any human being 'goes, and fights, against God's own ordinance'. Slavery, far from being decreed by God after the Fall, as Augustine maintained, is definitely against God's will. Not God, but human arrogance divided humanity into masters and slaves: Gregory repeats this statement in his On the Lord's Prayer: 'Not nature, but spirit of dominion

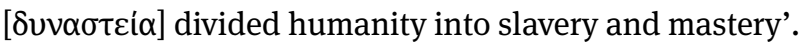

Gregory's condemnation of the institution of slavery is not limited to a Paschal homily and a homily on Ecclesiastes, but emerges constantly throughout his works. Gregory's injunction to all masters to free all of their slaves is rooted in his theology, on which his anthropology depends. Founding his position on theological arguments, in Homily 4 on Ecclesiastes Gregory claims that God's image, i.e. a human being, cannot, as a rational creature endowed with logos (and the Logos is Christ), be bought at any price. Gregory is founding his rejection of juridical slavery here upon the 'theology of the image'. Every human is free, qua image of God, who is free and powerful par excellence. God made each human person the owner of the whole cosmos; thus, no amount of money can buy a person: " I have bought for myself male and female slaves” [Eccl 2:7]. Please tell me: At what price? Among the existing beings, which have you found that is worth human nature? How many coins have you evaluated the logos? How may obols have you put on the scales as the price for God's image? Who can sell the being who is in the likeness of God, rules the whole earth, and has inherited from God power over 
all creatures on earth?' Only an insane man, deceived by the devil, could presume to be the owner of God's image: 'Has the devil tricked you into believing that you are the master of God's image? O what foolishness!' (Hom. Eccl. 4.337). Gregory's argument echoes 1 Tim 6:10, where the root of all sins is identified as greed for money (ibid., 4.339).

Gregory used another theological argument against both slavery and social injustice, besides the 'theology of the image': that from the 'social analogy', which argues for equality within the Trinity and within humanity. Freedom and equality within the Trinity - which Gregory supported in his anti-subordinationism (Ramelli 2011) - are reflected in freedom and equality among all humans. This argument is found in his treatise against the 'neo-Arian' Eunomius and elsewhere. For example, Gregory attacks Eunomius on the grounds that humans'

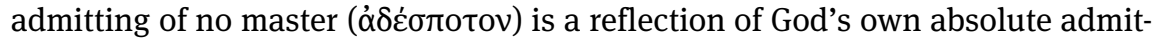
ting of no master. A similar position is also held in On the Lord's Prayer, GNO 7.2.70-1, where Gregory states that by nature only irrational creatures are slaves of rational ones. God has granted humans to be masters only of animals, not of other humans. Gregory reminds the master that his slave has the same worth as he himself from the viewpoint of the 'dignity of human nature'. In Against Eunomius (1.1.526, 3.1.15, 3.3.54-5, 3.4.37-8, 3.5.12, 3.8.44, 50, 53, 54-8), Gregory argues that, just as the divine nature cannot be divided into slavery and mastery, neither can human nature; the whole creation is a slave, but of God alone. Here, the analogy of the unity of nature in both divinity and humanity substantiates the claim that slavery cannot divide a nature that is one, whether this nature be divine or human.

Rachel Moriarty (1993) draws a parallel between some of Nyssen's statements on slavery in Homily 4 on Ecclesiastes and Seneca' Letter 47. On the basis of rhetorical resemblances, she concludes that Gregory's polemic against slavery is only apparent and drawn from rhetorical commonplaces, just as Seneca's advocacy of humane treatment for slaves did not entail a condemnation of slavery as an institution. But Gregory's theological arguments against slavery, based on the 'theology of the image' and 'social analogy', have little to do with Seneca's: they are grounded in the Bible and its philosophical interpretation, mainly in the light of Platonism. Gregory also adduces an eschatological argument. The elimination of slavery in the eschatological scenario will result from Christ's freeing of humans from slavery by voluntarily and lovingly taking slavery upon himself (C. Eun. 3.8). Because slavery cannot abide in the end, since it is against God's will and utterly impious and evil, it must be eradicated already now. This is why Gregory insisted that all people, not only ascetics, should free all their slaves.

The theological arguments that buttress Nyssen's condemnation of legal slavery are the same as those which underpin his condemnation of social injus- 
tice and usury, the causes of the dire poverty of many. Gregory joined Origen's, John Chrysostom's, and Evagrius' conviction that excessive wealth is tantamount to theft (Ramelli 2016, 199, 204-7). From the socio-historical viewpoint, Gregory's attitudes toward poverty and slavery are grounded in the prevalence of debt slavery in Gregory's own day, and in the practice of Gregory and other members of his family, such as Naucratius and Macrina, who rejected both riches and slave ownership altogether. This life choice was profoundly admired by Gregory, who, in the footsteps of Origen, Pierius, Pamphilus, Eusebius, and other Origenians, identified the philosophical life with a life of asceticism and voluntary poverty. Thus, in Against Fate 34.3 he remarks that the highest kind of life is a life 'without possessions'.

The 'theology of the image' is the main basis for Gregory's condemnation of not only slavery but also social injustice. In On Doing Good (GNO 9.1.93-108) Gregory maintains that nobody can be considered to be less worthy than others, since all humans are the image of Christ, who is the image of God. Christ has given his very countenance to all humans alike, in that he has taken up all humanity and has become incarnate in all humans. Gregory expressly refers to Matt 25:35-45, where Jesus identifies himself precisely with the poor: 'I was hungry and you gave me food, I was thirsty and you gave me drink [...] I was naked and you clothed me, I was sick and imprisoned and you visited me [...] as you did it to one of the least of these brethren, you did it to me'.

God has given the goods of this world to all humanity equally; therefore, those who possess more than they need are in fact depriving other people of what they need. ${ }^{6}$ Wealth is tantamount to theft; Gregory thus exhorts his flock to refrain from unjust acquisitions and love for riches: 'stay away from iniquitous gain, starve your idolatrous greed for riches: let nothing be stored up in your house that comes from violence and robbery' (On Doing Good 94). When Gregory claims that those who have more than the necessary are thieves who have stolen the necessities from the poor, he is following Origen, who insisted that whatever one acquires must be acquired with justice. If one acquires a great deal of wealth, this is necessarily acquired by means of injustice: 'They do not consider whether they gain in the right way, with justice [...] One of the following two alternatives must necessarily be the case: either to gain a lot by means of injustice, or only a little, but with justice [...] abundant riches are tantamount to iniquity' (Homily 3 on Psalm 36.6).

6 See also Basil, Homily 6 (cf. 7, 8) and Nazianzen, Oration 14.24-6. The principle that one's possessions should not exceed one's needs was supported by Epicureanism in antiquity: see Morel 2016. 
Ascetic practices, such as fasting and abstinence, are not appreciated by God, if one is oppressing one's brothers. Taking away necessities from the poor means 'biting your brother with wickedness' and 'drinking their blood out of evilness'. Judas also fasted, but his greed for money caused him to sell Jesus: greed for money is thus worse than failing to practice fasting and other pious deeds (Benef. 94-5). Corporeal fasting is useless, 'if the intellect is not purified. Self-restraint is

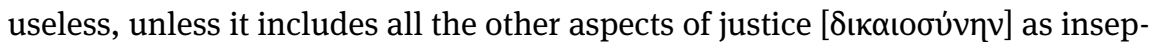
arable and consequent [...] Isaiah asks: To what end do you fast, while you strike the poor with your fists?' Like Gregory, John Chrysostom too warned that alms deriving from the degrading of other people are not welcome to God, who deems such a person a murderer. Therefore, John exhorts his audience 'to abstain from greed first' and then show mercy through alms (Hom. in 2Cor. 4:13, PG 51.300).

According to Gregory, as well as to Origen and other ascetics, asceticism must pair acts of self-restraint with justice. Gregory invites his flock to share their food and houses with the poor: the fact that they are poor is itself a grave $\alpha \delta$ เкi $\alpha$ (Benef. 96-7). Again, he avails himself of a theological argument: fear of God should eliminate social and economic inequalities, by becoming 'a just balancer who makes

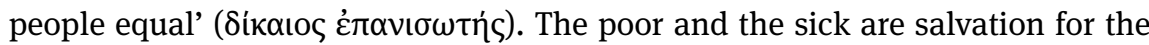
rich: 'Hug the disadvantaged as your own health, as the salvation of your wife and your own children' (Benef. 97-8). This is a threat: if the rich do not share their wealth with the poor then their own health and salvation, and those of their families, will be in danger. 'Do not despise the poor who lie down as worthy of nothing. Consider who they are, and you will find out their value/dignity [ $\alpha \dot{\alpha} \zeta \omega \mu \alpha]$ : they have put on the very countenance of our Saviour. He, who loves humanity, lent them his own face'. This echoes the theology of the image and Matt 25:35-45.

To the argument from the theology of the image - the poor have Christ's countenance - Gregory adds another in On Doing Good 101-13: God made creation for all humans in equal share. All should limit themselves to the possession of what they need, because the rest belongs to the poor, whom God loves: 'Put limits to the needs of your life! [...] Let a part of your wealth belong to the poor, God's beloved. For all goods belong to God, the common Father of all [...] we are all siblings, from the same race. It is better and more just if siblings participate in their heritage in equal parts'. Gregory accuses those who refuse to give the poor one third or one fifth of their goods (ibid., 104). In On Doing Good 106-8, Gregory alludes to the parable of Dives and Lazarus - on which he expands also in $D e$ anima - and warns the rich who give nothing to the poor that they may die in a few days and the abyss awaits them. Elsewhere, too, Gregory condemns injustice

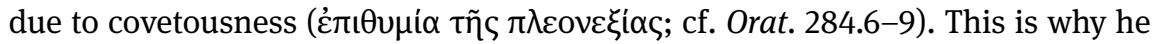
is so severe against covetousness, calling it 'madness incapable of controlling itself', inspired by the devil (Orat. 286.1-9). In On Usury 9.201.25-9, Nyssen warns 
the usurer, too, that his alms are unwelcome to God, since they come from his siblings' tears, flesh, and blood.

For Nyssen, renouncing the oppression of others through slavery or robbery and wealth is tantamount to robbery -, and thereby pursuing justice, is a matter of asceticism. Asceticism cannot possibly do without the renunciation of all forms of oppression. This connection was already at work in the Sentences of Sextus, a Christianised version of Pythagorean asceticism (see Ramelli 2016, Introduction; 2016a), but Gregory makes it stronger. No Christian, according to him, can practice asceticism, even in the mild forms of fasting or almsgiving, and at the same time own slaves or keep the riches that imply the impoverishment of other people.

\section{Other source texts: from Essenes and Therapeutae to late antique and Byzantine sources: asceticism and authority}

My source texts, besides those by Nyssen, range from the accounts given by Philo and Josephus of the rejection of slavery and social injustice by the ascetic Essenes and Therapeutae to late antique and early Byzantine sources concerning individuals or couples who emancipated their slaves and gave up their possessions in favour of the poor upon embracing the ascetic life, as well as monastic groups who liberated all the slaves who joined their communities, and the institutional reaction of the Church of the Empire to this destabilising practice. In the case of Byzantine monasteries, asceticism could be a way to liberate slaves. Some monasteries, as we shall see, kept fugitive slaves as ascetics, even refusing to return them to their owners.

It is correct, on the one hand, that, as Rebecca Krawiec (2008, 5) notes, 'asceticism emerges as a means of legitimating authority, rather than simply a set of religious practices'. This may have been the case, for instance, with bishops or other male authorities claiming control over female ascetics. But asceticism could also be subversive vis-à-vis authority, both ecclesiastical and social. This is proved by the fact that, as we shall see, the 'official' church had to intervene repeatedly to curb those ascetics' revolutionary practice of freeing slaves against their masters' will when they entered the monastic life. That meant subtracting slaves from the authority of their owners and from the social system in which slavery as an institution was embedded. And those ascetics who continued that practice with regard to slaves also went against the ecclesiastical authority that ordered the preservation of the social-legal status quo. 


\subsection{Essenes and Therapeutae}

Centuries earlier, the Jewish groups of Essenes and Therapeutae were already refusing slavery and social iniquity, both de jure and de facto. These groups represent an important strand of philosophical asceticism that had its roots already in Greek philosophy. Their rejection of slavery went hand in hand with their ascetic lifestyle, which, in the case of the former, according to Philo, entailed total dispossession. In Philo's report, the Essenes voluntarily had neither money nor possessions

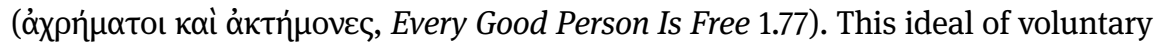
poverty, as well as of the rejection of slavery, was to be exalted by Nyssen, with specific reference to his family, and became a standard feature in Christian monasticism. The link between asceticism, poverty, and philosophy, which was taken over in the tradition of Origen, Pamphilus, Eusebius, Nyssen, and Evagrius, is particularly clear in Philo's description of the Therapeutae in On Contemplative Life.

According to Sharon Weisser (2010, 308), neither Philo nor Nyssen aimed at the establishment of social justice but merely condemned the vanity and arrogance of slave ownership. This was indeed the case with Philo, who did not share the ideals of the Essenes and the Therapeutae and did not personally reject slave ownership. But the Essenes and Therapeutae themselves - at least as represented by our sources -, as well as Nyssen, did focus on injustice ( $\alpha \delta ı \kappa^{\alpha} \alpha$ ) in their discourse about the rejection of slavery and social injustice. Jodi Magness, in a personal conversation at Metochi in summer 2013, endorsed the historicity of the Essenes and the Therapeutae and of their rejection of slavery and possessions, but suggested that their reasons may have had more to do with ritual purity. If this was the case, Philo and Josephus translated these reasons into more Hellenistic and philosophical terms. The description of the Essenes, as Joan Taylor (2004) notes, resembles that of the Pythagoreans, due to the attribution of philosophical asceticism to both. Richard Finn (2015, Chap. 2) also deems the Therapeutae to be close to Levites, while Philo depicted them in a more philosophical light.

In pre-Christian antiquity, ascetic Essenes and the Therapeutae are the sole groups credited with unequivocally refusing both to keep slaves and to recognise slavery as an institution, on the grounds of the natural equality and kinship among all humans and an evaluation of slavery as intrinsically unjust. This presupposes a strong link between equality and justice. Philo of Alexandria, in the first half of the first century CE, spoke of the Essenes in Every Good Person Is Free 79. These 'Jewish sages', according to him, were superior in sanctity to all other sages with regard to 'love for God, for virtue, and for humans' (83). Philo informs us that these Essenes numbered over four thousand and their name derived from holiness/purity (óotótnৎ), which in itself suggests some form of asceticism. He describes them as 'servants of God' on account of their will to make their interior 
dispositions worthy of the divinity (75). Philo's definition, therapeutae of God, may indicate a connection with the Therapeutae to whom Philo devoted a treatise. They avoid all that which can arouse cupidity (78). They share their possessions, meals, and homes (86) in reciprocal solidarity and renunciation of ownership (87). What inspired their ascetic practices was 'freedom, which escapes every slavery' (88). This is also why they rejected slavery both de jure and de facto.

The characteristics of the ascetic lifestyle of the Essenes are described in more detail in a substantial section of Josephus' Jewish War (2.120-61): 'holiness/purity', rejection of pleasure as a vice, and the embrace of 'temperance and control of passions' and sexual renunciation (120). Some of them married, but only for the sake of begetting children (160-1); all 'despise riches' and practice 'communality of goods', so that among them 'one will nowhere see either abject poverty or inordinate wealth' (122), as was also the case in the first Jesuan community in Jerusalem. The link between the excessive wealth of some and the poverty of many others was later highlighted by patristic thinkers such as Origen, Evagrius, and John Chrysostom, as well as Gregory Nyssen. They equated riches with theft, in the conviction that the wealth of some was the cause of the poverty of others.

The corresponding Slavonic tradition of Josephus' Bellum expands on this: 'They have no kind of property, but among them all things are communal, both clothes and food'. When new members enter the community, 'all the resources of the community are put at their disposal, as though they were their own' (124). The adherents change their garments and shoes only when they are worn out and 'there is no buying or selling among them, but they give what they have to any in need, and receives from them in exchange what is useful to themselves. They are also freely permitted to take anything from any of their siblings without making any return' (127).

The Essenes 'help those deserving, when in need, and supply food to the destitute' (133-5). The vow they made consisted in piety toward the deity, justice toward humans, wronging nobody, hating injustice, keeping faith with all people, loving truth, and abstaining from stealing, unholy gain, and robbery (139-42). Note the insistence on justice and avoiding the oppression of fellow humans.

That the Essenes rejected slave ownership is explicitly attested by Philo, who in Prob. 79, reports that these ascetics not only kept no slaves at all, but also rejected the very institution of slavery. They 'denounced slave owners not only because of their injustice in violating the law of equality, but also due to their impiety in infringing the statute of Nature, who, like a mother, bore and reared all humans alike, and created them genuine siblings, not simply in name, but in very reality'. The Essenes refused to keep any slave, while most Stoics did not refrain from owning some or even many. The same passage by Philo confirms this: 'It is 
impossible to find even just one slave among them. On the contrary, all of them are free and serve each other.' This was also the lifestyle of the Therapeutae according to our sources. Josephus also reports that the Essenes kept no slaves because slavery is tantamount to injustice ( $\alpha \delta$ ıкí $\alpha$, Jewish Antiquities 18.21).

Thus, Philo and Josephus concur in implying that the Essenes did not simply reject slave ownership as part and parcel of their vow of lack of property

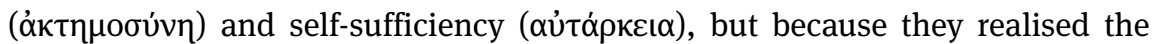
intrinsic injustice of the institution of slavery. This hypothesis is supported by Philo Prob. 79: the Essenes qualified the 'injustice' and 'impiety' that brought about the institution of slavery in terms of 'arrogance and avarice'. The natural kinship and equality of all humans was blurred by 'the triumph of the vicious arrogance and avarice' of some who began to oppress others.

The project of these ascetics, the Essenes and Therapeutae, was elitist, insofar as it only involved isolated ascetic groups, but it was undoubtedly also radical in its refusal of slavery both de jure and de facto, at least in the representation provided by the Hellenised Jews Philo and Josephus. The same position, that slavery and social injustice must be rejected because they entail the oppression of fellow humans, will be held by Christian ascetics such as Nyssen, but the latter thought that not only ascetics, but all humans should reject slavery and limit social injustice.

In his On Contemplative Life, Philo makes the rejection of slavery a core feature of the ascetic Therapeutae, both in a moral sense (18-20) and in a literal sense (70-2). In Cont. 18-20 Philo describes these people as "no longer slaves of anybody', because they have renounced all their possessions, including slaves, and all their relatives. In Cont. 70-2 Philo is not using the Stoic metaphor of moral slavery (on which see Ramelli 2016, Chap. 1): he testifies to the Therapeutae's radical rejection of the institution of slavery and relates this to their asceticism:

They receive service, but not by slaves, because they deem the possession of servants altogether against nature. For nature has generated all humans free; it is rather the acts of injustice and arrogance of some people who pursue inequality, the principle of all evils, that, accumulating upon one another, conferred to the stronger power over the weaker. Now, in this holy community, as I have said, nobody is a slave, but it is free people who serve other people, performing the necessary services not by force, nor waiting for orders, but anticipating the requests with zeal and willingness, voluntarily.

These services are not performed by any free person, no matter which, but it is rather the young of the group, selected on the basis of their excellence, who do so with every solicitude, in the way that becomes noble and distinguished people who strive for the highest virtue. These young people, as legitimate children, diligently and happily serve fathers and mothers, deeming them their own common parents, closer to themselves than their biological parents. For nothing is closer and more familiar to the wise than excellence in virtue. And while they perform these services, they wear no belt and let their short frocks hang down free, to avoid bringing even just a shade of slavish appearance. 
The motivations for the Therapeutae's rejection of slavery are similar to those of the Essenes.

Both were ascetic groups stemming from Hellenistic Judaism and roughly contemporary with one another. The tenet that all humans are free by nature fits well with a Stoic framework. However, the Therapeutae did not simply reject slavery in principle but actually refused to own slaves. And they did so not merely on the grounds of a Cynic requirement for $\alpha \kappa \tau \eta \mu o \sigma u ́ v \eta$, because they renounced all possessions, among which slaves were counted, but because they considered slavery, as an institution, to be against nature and an example of inequality, which is a fruit of injustice and arrogance, resulting in the oppression of others. Just as is the case with slavery, so too are the dire poverty of some and the exaggerated wealth of others instances of inequality among humans, which here is declared the principle of all evils.

Arguments against slavery and against social inequalities - replaced among Jewish ascetics by voluntary service and voluntary poverty - are very similar in these texts, as they will be again in Nyssen, who was well acquainted with Philo's writings. He approved of the Therapeutae's rejection of slavery and the freedom and promotion that asceticism offered to women, in this case the Therapeutrides, who were 'mostly aged virgins'. They are described by Philo as women who 'have kept their virginity without being forced to do so, unlike some Greek priestesses, but full willingly, out of their ardent desire for wisdom'. Voluntary asceticism, poverty, and service are identified as the highest freedom. Origen, Gregory, and other Christian ascetics agreed.

Junior Therapeutae served the elder, as children do their parents. In Decal. 2 Philo insists again on the rejection of injustice by the Therapeutae. Cities, from

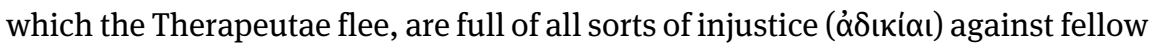
humans. The Therapeutae counted slavery among these, as did the Essenes. Some Christians, such as Eusebius, considered the Therapeutae described by Philo to be Christians (Ramelli 2011), thus idealising ascetics who refused slavery and embraced voluntary poverty. Indeed, it is from ascetics that the few condemnations of slavery in ancient Christianity arose.

\subsection{Asceticism of late ancient married couples and the giving up of slaves and possessions}

At the end of the fourth century and the beginning of the fifth, some married couples who embraced asceticism, such as the two Melaniae and Therasia and Paulinus of Nola, emancipated all of their slaves and renounced their immense wealth. Paulinus was born in Bordeaux from a very affluent family; a disciple 
of Ausonius, he became the governor of Campania. In 394/95 Paulinus and his Spanish wife Therasia decided to pursue a life of prayer and chastity, giving their possessions away to the poor and renouncing slave ownership. Ambrose delighted in Therasia's decision to give away all of her property and limit herself to Paulinus' 'tiny piece of turf' (Letter 6.27). Paulinus, ordained a priest, retired to Nola, close to the tomb of St Felix, became the bishop there, and promoted the cult of the saint. He also publicly renounced his senatorial seat, a decision that attracted much criticism on the part of his peers, including Ausonius.

After the death of her husband, when she was twenty-two years of age, Melania the Elder espoused asceticism in the form of renunciation of wealth and slaves. She gave up all her vast possessions and moved from Rome to Egypt, where she dwelt with the Origenian monks dubbed 'Tall Brothers', whom she followed to Palestine in 373. As ascetics, they kept no slaves, so Melania served them voluntarily in that capacity. She even wore 'the dress of a young slave' and, when the consular of Palestine had her thrown into prison, she proudly declared herself to be the daughter and wife of prominent noblemen, but also 'the slave of Christ', like Paul (Palladius, Lausiac History 46). She founded a double monastery in Jerusalem, which she directed and in which Rufinus too lived, supported by Melania as his patroness. For thirty-seven years she continued to give hospitality, to support churches and monasteries, strangers, and prisoners, her family, her son himself, and her stewards by providing money; finally, 'she possessed not even a span of land' and died 'having got rid of her possessions' (ibid., 54). Melania persuaded her own granddaughter, Melania the Younger, her husband, and her daughter-in-law Albina, to sell all their goods and become ascetics. She read virtually all of the literary production of Origen, Nyssen, and Basil seven or eight times (ibid., 55); thus, she absorbed Origen's ascetic ideals and the views on slavery and social justice of Gregory and Basil.

Indeed, Melania the Younger (Hunt 2016), aged twenty after the death of her two children, and her husband Pinianus decided to embrace monastic life, with the divestment of their massive wealth and the liberation of their slaves:

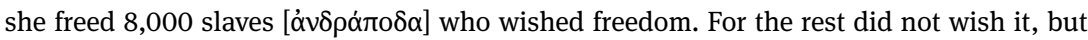
preferred to be slaves to her brother; and she allowed him to take them all for three pieces of money. But having sold her possessions in Spain, Aquitania, Tarragonia and the Gauls, she reserved for herself only those in Sicily, Campania, and Africa, and appropriated their income for the support of monasteries. Such was her wise conduct with regard to the burden of riches. And her asceticism was as follows. She ate every other day - to begin with after a five-day interval - and assigned to herself a part in the daily work of her own former slave-

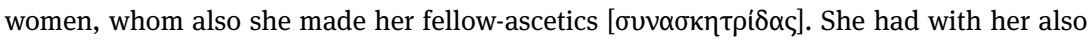
her mother Albina, who lived a similar ascetic life and distributed her riches for her part privately. Now these ladies are dwelling on their properties [...] with fifteen eunuchs and sixty virgins, both free and former slaves.

(ibid., 61) 
This report concurs with that by Gerontius, who, in his Life of Melania, represents Melania and Pinianus as renouncing the whole of their wealth as soon as they embraced asceticism. They may have kept some financial resources (Dunn 2014, 113-4) but they did not use them for their own comfort, as they embraced an ascetic lifestyle, but for helping the poor and other ascetics.

The example of these ascetics contributes to showing the connection between asceticism and the renunciation of slave ownership and wealth. For many patristic thinkers, and especially those of the Origenian-Evagrian line that was Melania's own bedrock, reducing one's wealth was just both in itself and for the sake of the poor, since wealth is tantamount to theft against them.

\subsection{Various categories of late antique ascetics and their relation to slavery and social justice}

Hermits or semi-hermits and extreme ascetics such as the stylites or dendrites who lived respectively on pillars and on trees -, as well as the other ascetics of Syria described by Theodoret in his Religious History, kept neither slaves nor possessions or much money. Simeon the Stylite (c. 390-459), who lived for forty years on a pillar, led a life both of extreme poverty, with restraints of all sorts, and of renunciation of slave ownership. In Religious History 26, Theodoret portrays Simeon's asceticism as philosophical, calling his ascetic life $\varphi$ ıлобо $\varphi$ i $\alpha$ and $\varphi$ флолоvi $\alpha$ (love for labour), and the monastery in which he spent ten years a 'school of philosophy'. According to the biography in Athanasius, 2-3, Antony (d. 356), the father of monasticism, , was inspired by Jesus' exhortation to sell all possessions and follow him, by the apostles' leaving everything to follow Jesus, and by Acts' description of the first Christian community as holding all possessions in common for the support of the needy (on this passage and its patristic reception see, e.g., Boulnois 2014). Antony renounced all his wealth when he embraced the ascetic life, gave the possessions of his forefathers to the villagers, and sold everything else that was movable, donating the revenues to the poor. Antony liberated or sold the slaves who, presumably, worked on his parents' estate, or he gave them, too, the land he owned when he distributed it to the villagers. He kept neither slaves nor possessions during his ascetic life.

Some monastic communities may have owned slaves not individually but in common. But in some monasteries, such as that of Macrina, this was not the case, since former slaves were freed before entering the monastery and did not have to serve therein. Both the ex-slaves and the free women served. In a work devoted to monasticism and attributed to Basil, the author insists that the monk must have no possessions whatsoever, having to embrace the 'life without possessions' 


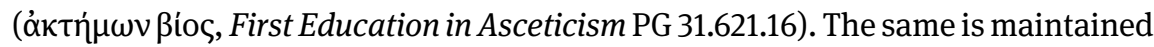
in another work attributed to Basil: a monk has first of all to enter an $\alpha \kappa \tau \eta \dot{\mu} \mu \nu$ Bíos (Ascetic Discipline, PG 31.648.42-3). We do not know whether here slaves could still be owned by the monastic community as a whole.

\subsection{Gregory of Nyssa's depiction of ascetics as models, his theory of 'spiritual asceticism', 'invisible religion', and individual and universal salvation}

Among the most significant texts that are relevant to the present investigation are those by Gregory of Nyssa, both his portrayal of model ascetics in the biohagiography of his sister Macrina and his theological arguments and exhortations against slavery and social injustice. As we shall see, Gregory seems to offer his portraits of Macrina, Naucratius, and other ascetics who embraced poverty and voluntary service and rejected slavery as a model for his readers to imitate.

Gregory called for 'spiritual fasting' and 'immaterial self-restraint' based primarily on the practice of justice, since he, like the Sentences of Sextus discussed above, maintained that ascetic practices such as fasting and almsgiving were not acceptable to God if one oppressed other people, kept slaves and excessive wealth, and did not practice justice. In On Doing Good 94, Gregory calls abstinence from oppressing other people 'spiritual asceticism':

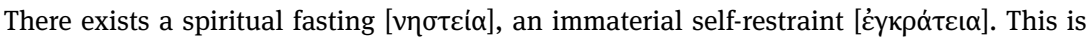
abstinence from sin, which pertains to the soul. Fast now from evil! Control yourself in your greed for what belongs to others! Give up dishonest gains! Starve your idolatrous greed for money to death! Let nothing be stored up in your house that comes from violence and robbery. It is to no avail that you maintain meat far from your mouth if you bite your brother out of evilness. It is to no avail that you keep strict frugality by yourself if you rob the poor with injustice. What kind of devotion makes you drink mere water, while with your machinations you ignobly deceive someone else and drink their blood?
}

Ascetic practices are in vain if one does not renounce the oppression of other people by means of such things as slavery, usury, and theft, which are described as 'injustice' and 'evil'. This position was inherited by the Evagrian Cassian: fasting is not only abstinence from material food but also fasting spiritually (Inst. 5.21.1): abstaining from greed, amassing wealth, owning slaves, etc. Abba Theodore is reported to have deemed it best to possess nothing, not even books (Apophthegmata Patrum, alphabetic series, Theodore of Pherme 1, PG 65.188).

Macrina, the sister of Basil the Great and Gregory of Nyssa, a lady coming from a rich and noble family, lived in a house-monastery - led by herself - like, 
later, the Mediaeval noble ladies Gertrude Rickeldey of Ortenberg and Heilke of Staufenberg (see Mulder-Bakker in this section). Gregory's bio-hagiography of Macrina and her fellow nuns (Ramelli 2019) could indeed be seen as an indicator of an intended institutionalisation of individualisation (bearing in mind that 'processes of religious individualisation are closely connected to the formation of institutions and traditions, and the interactions among them must be systematically examined', as remarked by Fuchs et al. 2016a, 11), for Gregory wanted all Christians - and not only strict ascetics - to renounce slave ownership as well as wealth that exceeds one's needs. Likewise, the biographers of those late antique ascetics who renounced all wealth and all slaves upon the embrace of what they represented as philosophical asceticism arguably intended to produce models to be followed. Thus, while on the one hand the house monastery of Macrina and those late antique ascetics who espoused asceticism and rejected wealth and slave ownership provide types of privatisation and 'invisible religion' (Rüpke 2015, 347) - to the point that Gregory Nazianzen exalted the secrecy and hiddenness of the life of Macrina (Ramelli 2010) -, on the other hand, the accounts of Gregory and the biographies of the other ascetics were intended to provide ideal models of religious and societal practices for a wide range of people.

Nyssen's attitude and intention can be contrasted with that of Philo: the latter reported the radical views and behaviour of Essenes and Therapeutae against slavery, private property, and social injustice, but he did not aim at providing a viable model for many people. For, unlike Gregory, Philo deemed slavery indispensable to relieve masters of menial tasks (On special laws 2.82, 2.123) and did not think that all should follow the example of the Therapeutae and embrace voluntary poverty and service, while renouncing slave ownership.

In the main exponents of Christian philosophical asceticism, it is possible to detect both an enhanced focus on the 'self' and individual salvation (on which see Fuchs 2015, 335; Ramelli 2019a), and, at the same time, a concern for, and theorisation of, universal salvation. Indeed, Nyssen, Macrina, and Evagrius, like their inspirer Origen, were all universalists in their soteriology (Ramelli 2013). But Origen and Gregory also stressed individual freewill. Indeed, Origen even made it a core feature of his antivalentinian polemic - and note its relevance to philosophical ethics, but also to social sciences and history, as highlighted recently by Ramsay MacMullen (2014). Moral responsibility is the gist of Origen's ethics and philosophical theology. In these religious thinkers we can see at work a focus on individual, experience-based spirituality in the mysticism and mystic apophaticism shared by Nyssen, Origen, and Evagrius (as argued by Ramelli 2018a). 


\section{Equality in different ascetic groups}

It is interesting to examine the different practices of these protomonastic and monastic communities or individuals, from Antony to Macrina, Naucratius, Melania, Evagrius, etc. A striking discrepancy can be observed regarding the retention or rejection of slave ownership and social hierarchy: Macrina liberated her slaves and made them her own peers, homotimoi, sharing the same works with them. But Paula, the ascetic, wealthy friend of Jerome's, in her housemonastery in Bethlehem, maintained all social distinctions, even emphasising them spatially (Jerome, Letter 108). Here, the virgins were not at all ó were divided into three classes: noble, middle, and lowest. They worked and ate separately, only joining together for psalmody and prayer.

Macrina, instead, lived together with her ex-slaves in her monastery, sharing her ascetic life with them. She and her siblings encouraged their household slaves to enter their proto-monastic community. In his bio-hagiography of his sister (Life of Macrina GNO 8.1.377.25-378.5), Gregory himself, full of admiration, recounts how Macrina convinced her mother Emmelia to join her ascetic community and live together with their own former slaves, now made 'of equal dignity' (ónótıoเ) with their ex-masters. Emmelia made 'all the slaves and servants she had, her

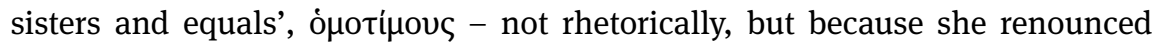
being served by her ex-slaves: she 'gave up the services performed by her slaves'. In 381.22-7, the keyword ó $\mu$ ó $1 \mu$ o in reference to Emmelia and her former slaves is repeated, and further details about Emmelia's equality with her former slaves are given: she shared the same table and the same kind of bed with them. Religious ascetic communities such as this mostly worked in a manner closer to the 'gift-exchange mode' delineated in this section by Herrmann-Pillath than in the 'market-exchange mode'.

Gregory emphasises that for Emmelia, Macrina, and their family, embracing ascetic life coincided with giving up being slave owners. Thus, Gregory draws a close connection between asceticism - the 'angelic life' - and rejection of slavery. Gregory also extols his brother Naucratius for adopting 'a life without posses-

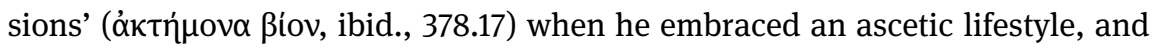

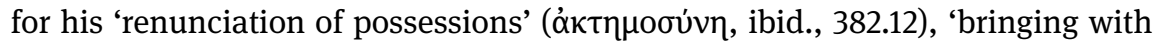
himself nothing else than himself'. Naucratius accepted that one of his former slaves followed him, not to be served by him, but to share 'the same life choice with him' (ibid., 378.19-21). Far from being served by his ex-slave, Naucratius made himself a servant of the poor, old, and ill (379.6-7). Naucratius and Peter, the future bishop of Sebaste, in the same biography of Macrina, are exalted as ascetics by their brother Gregory far more than is Basil. Naucratius is praised for refusing any ecclesiastical position and for privileging asceticism and poverty. 
Peter is praised for cooperating with Macrina in the angelic life of asceticism and for being a faithful disciple of hers, who was his 'father, professor, pedagogue, mother, and counsellor of every good' (Life of Macrina, 12.11-13, 27-30). Asceticism is again paired with total renunciation of slave ownership, and even voluntary self-assimilation to slaves, as well as voluntary poverty.

\section{Conflict between ascetic groups and the 'Church of the Empire': ascetic impulse to 'de-traditionalisation'}

This investigation offers valuable avenues for reflection on the institutionalisation of forms of religious individualisation, especially with respect to the institutionalisation of asceticism in ecclesiastical structures and the attitudes of ascetics and ascetic groups toward social justice and slavery. I think, for instance, of Eustathius of Sebaste (in Armenia-Pontus), depicted as a philosophical ascetic committed to social justice and the liberation of slaves independently of their owners' consent, the official church reaction at the Synod of Gangra in the 340s against the practice, promoted by Eustathius and his followers, of liberating slaves even without their owners' consent, and the resistance of monastic groups to this official ecclesiastical reaction. Eustathius was an ascetic who supervised a hospice for the poor in the 350s CE. He likely inspired Basil's plan for his own hospice for the needy. Basil himself, in Letter 244, testifies that he had upheld Eustathius as a model since his youth. Socrates relates that Eustathius was the son of Eulalius, the bishop of Caesarea in Cappadocia, the same seat as Basil the Great held, but Eulalius deemed his son unfit for the priesthood and the episcopal dignity (Church History 2.43).

Eustathius organised almshouses, hospitals, refuges, and the like (Epiphanius, Against Heresies 75.1 and Sozomen, Ecclesiastical History 3.14.36). He was the teacher of Macrina and Basil, who both emphasised asceticism and the rejection of slavery and social injustice. But Macrina, Basil, and Nyssen mitigated Eustathius' radicalism, dropping especially the prohibition of marriage, at least for non-ascetics. Socrates relates Eustathius' teaching and activity, which was full of ascetic traits, and attests to Eustathius' commitment to the liberation of slaves independently of their owners' consent:

He forbade marriage and taught as a dogma that it was necessary to abstain from foods. This is why he separated many people who were married from their partners and persuaded those who were averse to churches to make communion in private houses. He also snatched 
slaves from their masters under the pretext of piety. He wore philosophical garb himself, and had his followers wear a strange outfit, and women cut their hair. He also taught to neglect the prescribed fasting days and rather fast on Sundays, and prohibited praying in the houses of married people. He prescribed to decline as a defilement the blessing and communion of a presbyter who had a wife, even if he had married her according to the law while he was still a layman.

(Church History 2.43)

A synod at Gangra, in Paphlagonia, in the 340s, not only prohibited the liberation of slaves in monasteries against their owners' consent, as we shall see in the next paragraph, but in Canon 12 also forbade the use of the philosopher's mantle for the sake of asceticism - and Eustathius is presented by Socrates as a philosopher. He is said to have worn philosophical attire even when he was a bishop, like Heraclas of Alexandria according to Origen. In a letter reported by Eusebius (Church History 6.19.12-4), Origen defended his interest in philosophy, which he never abandoned. He adduces the examples of Pantaenus and Heraclas, both Christian philosophers in Alexandria. Pantaenus had an excellent preparation in philosophy and Greek disciplines, and Heraclas, the future bishop of Alexandria, 'who now sits in the $\pi \rho \varepsilon \sigma \beta v \tau \varepsilon$ pı dressed as a philosopher. He was still wearing philosophical garb and studying the 'books of the Greeks' when Origen wrote his letter. There was a connection between Eustathius' being a philosopher and his asceticism, which surely had an impact on his rejection of slavery. Asceticism and philosophy went together in Origen's life, too, according to Pamphilus and Eusebius, and in Philo's life, according to Eusebius - who modelled his portrait of Philo on that of Origen (Ramelli 2011a).

Eustathius and his followers were condemned by the above-mentioned synod at Gangra for their teachings, including, most prominently, their campaign for the liberation of slaves. Sozomen, Church History 3.14.36, reports that Eustathius submitted to this council, but an Antiochian synod condemned him again for 'perjury' (ibid., 4.24.9). The official teaching of the 'Church of the Empire', as expressed in the third canon of Gangra, was that slavery had to be retained as an institution. The canon condemned to excommunication those who exhorted slaves to stop serving their masters, which they should have done, moreover with respect and goodwill, as the deutero- and pseudo-Pauline house codes commanded (on which see Ramelli 2016, Chap. 2).

A century later, the fourth canon of the Council of Chalcedon ( $451 \mathrm{CE}$ ) again forbade monasteries from offering refuge to runaway slaves without the permission of their masters. The reiteration of the prohibition suggests that ascetic groups had meanwhile continued to free slaves against their masters' will. Monasteries were used as asylum for runaway slaves (Rotman 2009, 144-50). This confirms that many ascetics within the church rejected slavery, as some Jewish and perhaps some 'pagan' philosophical ascetics had already done. 
Zeno decreed that slaves, provided that their masters agreed, should be allowed to participate in monastic life (484 CE). As long as they continued to be monks, their owners had to renounce the exercise of ownership and lordship over them. But if those former slaves left the monastic life, they would automatically return to the condition of slaves (Codex Iustinianus 1.3.37). This points again to a strong connection between ascetic life and the rejection of slavery. The focus in this case is not on a slave owner who renounces the keeping of slaves when he or she embraces asceticism, but rather on the slave himself or herself, who is freed from a condition of enslavement upon adhesion to asceticism.

However, the need for the slave owner's permission severely limited the effects of Zeno's decree, whereas monks such as those condemned at Gangra and at Chalcedon acted independently of the consent of masters. Eustathius and his followers were undermining the institution of slavery both in monasteries and even in society at large.

The connection between asceticism, monasticism, and the rejection of slavery becomes especially clear in the age of Justinian, when monasteries were allowed to receive fugitive slaves who intended to become monks, unless they perpetrated a crime. However, the legal owner of these slaves could still reclaim their slaves within three years of their embracing the monastic life (Rotman 2009, 144-5). Another open issue, as I mentioned, is that of the possibility for the monastery as a whole to own slaves collectively, as opposed to individual ownership of one or more slaves. However, monasteries - the stronghold of asceticism - appear as the single space where slaves could actually gain independence from their owners. In some cases, poverty was mandatory not only for the individual monks, but also for the monastery as a whole. For instance, Cassian, in the early fifth century, exhorted monks to give up wealth not only individually, but also collectively: the monastery itself had to be poor and to renounce endowments from its members or rich donations from outside. And in Conferences 18, Cassian observes that the true monks are those who reproduce the lifestyle of the first Christian community as depicted in Acts - although in Acts the point was not poverty, but the sharing of possessions.

As in the case of the Eleusinian mysteries, not only is participation in ascetic-monastic life based on personal choice, but individual initiation promises a change of fate in the afterlife (see Patera's paper in this section). The main difference is that the Eleusinian mysteries were run by the polis, while monasteries were, in many cases, not a direct expression of political power and, indeed, sometimes came into overt conflict with it, such as when they liberated slaves against the will of their masters. This went not only against the Roman institution of slavery, but also against the church's official decree at Gangra.

The present investigation also seems to bear on, and support the notion, of de-traditionalisation as described by Jörg Rüpke $(2013,7)$, in which 'individual 
action is less and less determined by traditional norms handed down by family and the larger social context'. Indeed, those who rejected slave ownership and possessions were going against societal norms and even the institution of slavery itself, which was a pillar of ancient society and economy; hence also the harsh criticism of 'pagan' polemicists against Christian ascetics as destroyers of society (Ramelli 2016, 219-20). Already Celsus criticised Jesus' claim that the rich have no access to God, and that people should not be concerned with food, granary attics, clothes and wealth (Origen C. Cels. 7.18). The practices of Eustathius and his followers, as well as monastic resistance to Gangra, clearly questioned established religious and societal norms, concepts, and institutions.

\section{References}

Boulnois, Marie-Odile. 2014. 'La communauté chrétienne primitive d’Actes 2:44-47 chez les Pères grecs'. In Actes 2:44-47: La communauté des biens, ed. G. Dahan, Paris: Vrin. 53-98.

Brown, Peter. 1988/2008. The Body and Society: Men, Women, and Sexual Renunciation in Early Christianity. New York: Columbia / 20th anniversary edition with a new introduction.

Dunn, Geoffrey. 2014. 'The Poverty of Melania the Younger and Pinianus', Augustinianum 54.1. 93-115.

Dunn, Geoffrey; Mayer, Wendy (eds.). 2015. Christians Shaping Identity from the Roman Empire to Byzantium: Studies Inspired by Pauline Allen. Leiden: Brill.

Feldman, Fred. 2016. Distributive Justice: Getting What We Deserve from Our Country. Oxford: Oxford University Press.

Finn, Richard. 2015. Almsgiving in the Later Roman Empire: Christian Promotion and Practice 313-450. Oxford: Oxford University Press.

Fuchs, Martin. 2015. 'Processes of religious individualisation: stocktaking and issues for the future', Religion 45.3. 330-43.

Fuchs, Martin; Rüpke, Jörg. 2015. 'Religious individualization in Historical Perspective', Religion 45.3. 323-9.

Fuchs, Martin; Mulsow, Martin; Rüpke, Jörg. 2016. 'Preface'. In First Results of the Second Funding Period of the Research Group 'Religious Individualisation in Historical Perspective' (2013-2015): A Reader, ed. R. Suitner, Erfurt: Max Weber Centre, Universität Erfurt. 5-6.

Fuchs, Martin et al. 2016. 'Religious Individualization in Historical Perspective: Research Program 2014-17'. In First Results of the Second Funding Period of the Research Group 'Religious Individualisation in Historical Perspective' (2013-2015): A Reader, ed.

R. Suitner, Erfurt: Max Weber Centre, Universität Erfurt. 9-24.

Griffin, Svetla S.; Ramelli, Ilaria (eds.). 2019. Lovers of Souls and Lovers of Bodies: Philosophical and Religious Perspectives in Late Antiquity. Center for Hellenic Studies: Harvard University Press.

Harmless, William. 2008. 'Monasticism'. In The Oxford Handbook of Early Christian Studies, Oxford: Oxford University Press. Online edition 2009, Chap. 24. 
http://www.oxfordhandbooks.com/view/10.1093/oxfordhb/9780199271566.001.0001/ oxfordhb-9780199271566-e-025

Hunt, E. D. 2016. 'Melania the Younger'. In Oxford Classical Dictionary, Oxford: Oxford University Press. Online edition 2016: http://classics.oxfordre.com/view/10.1093/ acrefore/9780199381135.001.0001/acrefore-9780199381135-e-6999.

Krawiec, Rebecca. 2008. 'Asceticism'. In The Oxford Handbook of Early Christian Studies, ed. Susan A. Harvey and David Hunter, Oxford: Oxford University Press. Online edition 2009, Chap. 37. http://www.oxfordhandbooks.com/view/10.1093/oxfordhb/9780199271566. 001.0001/oxfordhb-9780199271566-e-038.

Logan, Dana. 2017. 'The Lean Closet: Asceticism in Postindustrial Consumer Culture', JAAR 85.3. 600-28.

MacMullen, Ramsay. 2014. Why Do We Do What We Do? Motivation in History and the Social Sciences. Berlin: DeGruyter Open.

Markschies, Christoph. 2014. 'Individuality in some Gnostic authors, with a few remarks on the interpretation of Ptolemy's Epistle ad Floram'. In Individuality in Late Antiquity, eds.

A. Torrance, J. Zachhuber, Burlington: Ashgate. 11-28.

Morel, Pierre-Marie. 2016. 'Épicure et les biens matériels, ou la pauvreté bien tempérée’. In Richesse et pauvreté chez les philosophes de l'Antiquité, ed. É. Helmer, Paris: Vrin. 111-24.

Moriarty, Rachel. 1993. 'Human Owners, Human Slaves: Gregory of Nyssa, Hom. Eccl. 4', StudPatr 27. 62-9.

Otto, Bernd-Christian. 2017. 'Magic and Religious Individualization: On the construction and deconstruction of analytical categories in the study of religion', Historia Religionum 9. 29-52.

Priesching, Nicole; Grieser, Heike (eds.). 2016. Theologie und Sklaverei von der Antike bis in die frühe Neuzeit. Hildesheim: Olms.

Ramelli, Ilaria. 2010. 'Theosebia: A Presbyter of the Catholic Church', Journal of Feminist Studies in Religion 26,2. 79-102.

Ramelli, Ilaria. 2011. 'Origen's Anti-Subordinationism and Its Heritage in the Nicene and Cappadocian Line', Vigiliae Christianae 65. 21-49.

Ramelli, Ilaria. 2011a. 'The Birth of the Rome-Alexandria Connection: The Early Sources on Mark and Philo, and the Petrine Tradition', Studia Philonica Annual 23. 69-95.

Ramelli, Ilaria. 2016. Social Justice and the Legitimacy of Slavery: The Role of Philosophical Asceticism from Ancient Judaism to Late Antiquity. Oxford: Oxford University Press.

Ramelli, Ilaria. 2016a. 'The Sentences of Sextus and the Christian Transformation of Pythagorean Asceticism'. In Pythagorean Knowledge from the Ancient to the Modern World, eds. A. B. Renger, A. Stavru, Wiesbaden: Harrassowitz, 151-62.

Ramelli, Ilaria. 2018. 'Origen'. In A History of Mind and Body in Late Antiquity, ed. A. Marmodoro, Cambridge: Cambridge University Press, 245-266.

Ramelli, Ilaria. 2018a. 'Mysticism and Mystic Apophaticism in Middle and Neoplatonism'. In Constructions of Mysticism as a Universal: Roots and Interactions Across the Borders, ed. A. Wilke, Wiesbaden: Harrassowitz.

Ramelli, Ilaria. 2019. 'The Life of Macrina.' In Novel Saints: https://dev.novelsaints.ugent.be/ node $/ 1045 /$.

Ramelli, Ilaria. 2019a. 'Autobiographical Self-Fashioning in Origen.' In Self, Self-Fashioning and Individuality in Late Antiquity: New Perspectives, ed. M. Niehoff, J. Levinson, Tübingen: Mohr Siebeck, 2019, 271-288.

Ramelli, Ilaria. Forthcoming a. 'Social Justice and Slavery in the Bible.' In Oxford Biblical Studies Online, Oxford: Oxford University Press, forthcoming: http://global.oup.com/obso/focus/ 
Ramelli, Ilaria. Forthcoming b. 'Christian Slavery in Theory and Practice'. In The Cambridge History of Ancient Christianity, eds. Bruce Longenecker and David Wilhite, Cambridge: CUP, forthcoming.

Rotman, Youval. 2009. Byzantine Slavery and the Mediterranean World, trans. Jane Todd. Cambridge, MA: Harvard University.

Rüpke, Jörg. 2011/2016. Aberglauben oder Individualität? Religiöse Abweichung im römischen Reich. Tübingen: Mohr Siebeck = Religious deviance in the Roman world: superstition or individuality? Revised and enlarged edition, trans. D. Richardson. Cambridge: Cambridge University Press.

Rüpke, Jörg (ed.). 2013. The Individual in the Religions of the Ancient Mediterranean. Oxford: Oxford University Press.

Rüpke, Jörg. 2013a. 'Individualization and Individuation as Concepts for Historical Research'. In The Individual in the Religions of the Ancient Mediterranean, ed. Idem, Oxford: Oxford University Press. 3-38.

Rüpke, Jörg. 2014. From Jupiter to Christ: On the History of Religion in the Roman Imperial Period. Oxford: Oxford University Press.

Rüpke, Jörg. 2015. 'Religious agency, identity, and communication: reflections on history and theory of religion', Religion 45.3. 344-66.

Rüpke, Jörg. 2016. On Roman Religion: Lived Religion and the Individual in Ancient Rome. Ithaca: Cornell University.

Satlow, Michael. 2005. 'Giving for Return: Jewish Offerings in Late Antiquity'. In Religion and the Self in Antiquity, eds. D. Brakke, M. Satlow, S. Weitzman, Bloomington: Indiana University. 91-108.

Schultz, Celia. 2016. 'Roman Sacrfice, Inside and Out', JRS 106. 58-76.

Spickermann, Wolfgang; Rüpke, Jörg. 2012. Forms, Contexts, Media Reflexions on Religious Individuality: Graeco-Roman and Judaeo-Christian Texts and Practices. Berlin: de Gruyter.

Taylor, Joan. 2004. Pythagoreans and Essenes. Leuven: Peeters.

Weisser, Sharon. 2010. 'Philo's Therapeutae and Essenes: A Precedent for the Exceptional Condemnation of Slavery in Gregory of Nyssa?' In The Quest for a Common Humanity: Human Dignity and Otherness in the Religious Traditions of the Mediterranean, eds. K. Berthelot, M. Morgenstern, Leiden: Brill. 289-310. 